Edisi Januari - Juni 2020 Vol 19 No 1

\section{JURNAL ILMU PEMERINTAHAN}

\section{nakhoda}

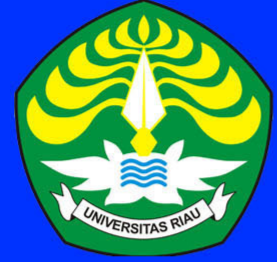

Innovation Hub: Media Kolaborasi Menuju Pemerintahan Daerah Inovatif Herie Saksono

Institusional Building dalam Mengatasi Persoalan Pertambangan Emas Tanpa Izin Di Kabupaten Kuantan Singingi Provinsi Riau

Khotami

Gerakan Masyarakat Tertib Administrasi Kependudukan Melalui Inovasi Pelayanan Lukadesi (Keluarga Berduka Desa Siaga)

Di Kabupaten Sleman D.I Yogyakarta

Hendy Setiawan, Fariza Ikhsanditya

Provinsi 'Istimewa Melayu Riau Kepulauan'

Muchid Albintani, Auradian Marta

Kaderisasi dan Penetapan Calon Legislatif pada Partai Politik (Studi DPD Partai Nasional Demokrat Seram Bagian Barat 2019)

Fandi Ahmad Sintani, Wahab Tuanaya, Marno Wance

Factors of Affect Deliberation of Maguwoharjo

Village Development Planing Sub-District Depok Regency Sleman Yogyakarta Muhammad Rafi, Ulung Pribadi, Fajar Rahmanto

Survey Kepuasan Masyarakat (SKM) pada Badan PendapatanDaerah Kabupaten Bintan

Suherry, Billy Jenawi, Rendra Setyadiharja,

Zamzami A Karim, Firman Setyawan, Rany Angraini

Peran Dewan Perwakilan Daerah (DPD) dalam

Pembentukan Daerah Otonomi Baru (DOB) Di wilayah Provinsi Maluku Utara

Abdul Halil Ibrahim, Bakri La Suhu, Rifjal Tifandy, Marno Wance

MEDIA INFORMASI DAN KOMUNIKASI ILMIAH CIVITAS AKADEMIKA JURUSAN ILMU PEMERINTAHAN

FAKULTAS ILMU SOSIAL DAN ILMU POLITIK

UNIVERSITAS RIAU
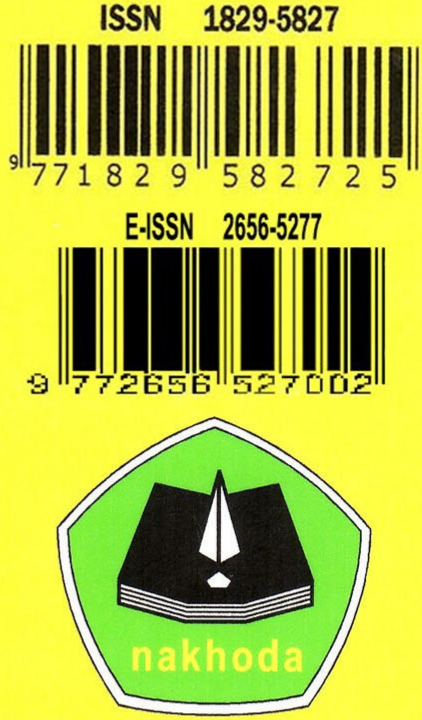

DITERBITKAN OLEH :

LABORATORIUM ILMU PEMERINTAHAN
SEKRETARIAT :

KAMPUS BINA WIDYA SIMPANG BARU

PANAM KM. 12,5 PEKANBARU

(28293) Telp/Fax. (0761)63277 
NAKHODA:

JURNAL

ILMU PEMERINTAHAN
NAKHODA: JURNAL ILMU PEMERINTAHAN

Edisi Januari - Juni 2020 Volume: 19 Nomor: 1

ISSN : 1829-5827 | E-ISSN : 2656-5277

DOI : https://doi.org/10.35967/jipn

https://nakhoda.ejournal.unri.ac.id/index.php/JIPN

INNOVATION HUB: MEDIA KOLABORASI MENUJU PEMERINTAHAN DAERAH INOVATIF

Herie Saksono

Badan Penelitian dan Pengembangan (BPP) Kementerian Dalam Negeri, Jakarta, Indonesia

$1-16$

INSTITUTION BUILDING DALAM MENGATASI PERSOALAN PERTAMBANGAN EMAS

TANPA IZIN DI KABUPATEN KUANTAN SINGINGI PROVINSI RIAU

Khotami

Program Studi Ilmu Pemerintahan, Fakultas IImu Sosial dan IImu Politik Universitas Islam Riau. 17 - 37

Pekanbaru-Indonesia

GERAKAN MASYARAKAT TERTIB ADMINISTRASI KEPENDUDUKAN MELALUI INOVASI

PELAYANAN LUKADESI (KELUARGA BERDUKA DESA SIAGA) DI KABUPATEN SLEMAN

D.I. YOGYAKARTA

Hendy Setiawan ${ }^{1}$, Fariza Ikhsanditya ${ }^{2}$

1,2 Departemen IImu Pemerintahan, Universitas Muhammadiyah Yogyakarta, Yogyakarta,

Indonesia

PROVINSI “ISTIMEWA MELAYU KEPULAUAN RIAU” (GAGASAN PERMULAAN)

Muchid Albintani', Auradian Marta ${ }^{2}$

1,2 Jurusan IImu Pemerintahan, Fakultas IImu Sosial dan IImu Politik, Universitas Riau

KADERISASI DAN PENETAPAN CALON LEGISLATIF PADA PARTAI POLITIK (Studi DPD

Partai Nasional Demokrat Seram Bagian Barat 2019

Fandi Ahmad Sintani ${ }^{1}$, Wahab Tuanaya ${ }^{2}$, Marno Wance ${ }^{3}$

1,2,3 Jurusan IImu Pemerintahan, Universitas Pattimura, Indonesia

$75-90$

FACTORS THAT AFFECT DELIBERATION OF MAGUWOHARJO VILLAGE DEVELOPMENT

PLANNING SUB-DISTRICT DEPOK REGENCY SLEMAN YOGYAKARTA

Muhammad Rafi ${ }^{1}$, Ulung Pribadi2, Fajar Rahmanto ${ }^{3}$

1,2,3 Department of Government Affairs and Administration, Universitas Muhammadiyah

Yogyakarta, Indonesia

SURVEY KEPUASAN MASYARAKAT (SKM) PADA BADAN PENDAPATAN DAERAH

KABUPATEN BINTAN

Suherry ${ }^{1}$, Billy Jenawi², Rendra Setyadihardja ${ }^{3}$, Zamzami A. Karim4,

Firman Setiawan ${ }^{5}$, Rany Angraini ${ }^{6}$

$102-112$

1,2,3,4 STISIPOL Raja Haji, Tanjungpinang, Indonesia

5,6 Bapelitbang, Bintan, Indonesia

PERAN DEWAN PERWAKILAN DAERAH (DPD) DALAM PEMBENTUKAN DAERAH

OTONOMI BARU (DOB) DI WILAYAH PROVINSI MALUKU UTARA

Abdulhalil Hi. Ibrahim ${ }^{1}$, Bakri La Suhu2, Rifjal Tifandy 3 Marno Wance 4

1,2,3 IImu Pemerintahan Universitas Muhammadiyah Maluku Utara, Kota Ternate, Indonesia

$113-127$

${ }^{4}$ IImu Pemerintahan, Universitas Pattimura, Kota Ambon, Indonesia 


\title{
SURVEY KEPUASAN MASYARAKAT (SKM) PADA BADAN PENDAPATAN DAERAH KABUPATEN BINTAN
}

\author{
Suherry $^{1}$, Billy Jenawi ${ }^{2}$, Rendra Setyadihardja ${ }^{3}$, Zamzami A. Karim ${ }^{4}$, \\ Firman Setiawan ${ }^{5}$, Rany Angraini ${ }^{6}$ \\ 1,2,3,4 STISIPOL Raja Haji, Tanjungpinang, Indonesia \\ ${ }^{5,6}$ Bapelitbang, Bintan, Indonesia \\ Isuherry89@gmail.com, ${ }^{2}$ billyjenawi08@gmail.com, ${ }^{3}$ rendra.stisipolrajahaji@gmail.com, \\ ${ }^{4}$ zamikareem@gmail.com, ${ }_{5}^{5}$ firman298@gmail.com, ranyangraini7@gmail.com
}

\begin{abstract}
ABSTRAK
Pemerintah memiliki tugas penting dalah memberikan pelayanan kepada masyarakat, salah satunya adalah pelayanan administratif. Penelitian ini bertujuan untuk mengetahui tingkat kepuasan masyarakat terhadap pelayanan yang diberikan oleh Badan Pendapatan Daerah Kabupaten Bintan. Terdapat sembilan unsur yang menjadi penilaian berdasarkan Peraturan Menteri Pendayagunaan Aparatur Negara dan Reformasi Birokrasi Nomor 17 Tahun 2017 yakni Persyaratan; Sistem, Mekanisme, dan Prosedur; Waktu Penyelesaian; Biaya/Tarif; Produk Spesifikasi Jenis Pelayanan; Kompetensi Pelaksana; Perilaku Pelaksana; Penanganan Pengaduan, Saran dan Masukan; Populasi berjumlah 2.459 orang (Januari-Oktober 2019) yang mendapatkan pelayanan pada Badan Pendapatan Daerah Kabupaten Bintan. Sedangkan sampel yang diperoleh berdasarkan tabel Krejcie dan Morgan yakni 352 orang. Hasil penelitian menunjukkan terdapatada 2 unsur pelayanan yang mendapatkan mutu A (Sangat Baik) yakni berkaitan biaya/tarif dengan nilai indeks sebesar 90,84 skor senilai 3,634 dan unsur penanganan pengaduan, saran dan masukan dengan nilai indeks sebesar 88,99 skor senilai 3,560. Sementara tujuh unsur lainnyamemperoleh mutu B (baik) dengan urutan tertinggi yakni unsur kompetensi pelaksana dengan nilai indeks 85,95 skor nilai 3,438; unsur sarana dan prasarana dengan nilai indeks 84,52 skor nilai 3,381; unsur persyaratan yang mendapatkan nilai indeks sebesar 84,38 skor nilai 3,375; unsur perilaku pelaksana dengan nilai indeks 84,23 skor nilai 3,369; unsur waktu penyelesaian dengan nilai indeks 82,67 skor nilai 3,307; unsur produk spesifikasi jenis dengan nilai indeks sebesar 82,24 skor nilai 3,29; dan terakhir unsur sistem, mekanisme dan prosedur dengan nilai indeks 81,82 dengan skor nilai 3,273.
\end{abstract}

\section{Kata Kunci: Survey, Kepuasan Masyarakat, Pelayanan Publik}

\section{PENDAHULUAN}

Pemberian pelayanan yang terbaik kepada masyarakat di semua bidang kehidupan merupakan kewajiban yang harus dilaksanakan oleh Pemerintah. Oleh karena itu, pemerintah memiliki kewajiban dan bertanggungjawab untuk memenuhi hak publik dalam bidang pelayanan publik yang prima dan profesional. Pelayanan publik merupakan keharusan yang yang dilakukan oleh pemerintah dan hak yang harus didapatkan oleh masyarakat.

Seiring berjalannya waktu, masyarakat semakin kritis dan berani mengajukan tuntuan keinginan dan inspirasi kepada pemerintah serta melakukan kontrol terhadap apa yang dilakukan oleh pemerintah termasuk pelayanan publik. Untuk dapat meningkatkan pemberian pelayanan 


\author{
NAKHODA: JURNAL ILMU PEMERINTAHAN \\ Edisi Januari - Juni Tahun 2020 Volume: 19 Nomor: 1 \\ ISSN : 1829-5827 | E-ISSN : 2656-5277 \\ DOI : https://doi.org/10.35967/jipn \\ https://nakhoda.ejournal.unri.ac.id/index.php/JIPN
}

kepada publik, maka perlu dilakukan penilaian terhadap pelayanan yang diberikan oleh pemerintah agar dapat mengetahui kekurangan dalam pelayanan dan keinginan pemerintah.

Pemerintah telah mengeluarkan Peraturan Menteri Pendayagunaan Aparatur Negara dan Reformasi Birokrasi Nomor 14 Tahun 2017 tentang Pedoman Penyusunan Survei Kepuasan Masyarakat. Pedoman ini dikeluarkan untuk menggantikan pedoman sebelumnya yakni PermenpanRB No. 16 Tahun 2014 tentang Pedoman Survei Kepuasan Masyarakat terhadap Penyelenggaraan Pelayanan Publik. Peraturan sebelumnya dipandang terlalu umum dan bersifat tidak operasional sehingga memerlukan penjabaran teknis dalam pelaksanaannya. Sehingga perlu untuk disesuaikan dengan metode survei yang aplikatif dan mudah untuk dilaksanakan. Peraturan ini juga dimaksudkan untuk memberikan arahan dan pedoman yang jelas dan tegas bagi penyelenggara pelayanan publik.

Survey Kepuasan Masyarakat (SKM) dilakukan dalam rangka untuk mengetahui tingkat kepuasan masyarakat sehingga dapat meningkatkan kinerja pemerintahan di lingkungan Pemerintah Kabupaten Bintan yang bertujuan memberikan pelayanan publik kepada masyarakat untuk mewujudkan visi dan misi dan menjadikan "Bintan Gemilang". SKM dilakukan pada salah satu Organisasi Perangkat Daerah yang ada di Kabupaten Bintan yakni Badan Pendapatan Daerah. Badan Pendapatan Daerah Kabupaten Bintan, merupakan unsur pelaksana fungsi penunjang urusan pemerintahan daerah dibidang pengelolaan pajak dan retribusi daerah yang dipimpin oleh Kepala Badan yang berkedudukan dibawah dan bertanggungjawab kepada Bupati melalui Sekretaris Daerah.

Survey Kepuasan Masyarakat ini bertujuan untuk mendapatkan feed back/umpan balik atas kinerja/kualitas pelayanan yang diberikan kepada masyarakat guna perbaikan/ peningkatan kinerja/kualitas pelayanan secara berkesinambungan khususnya pelayanan yang dilakukan oleh Badan Pendapatan Daerah Kabupaten Bintan.

Unsur-unsur yang termasuk dalam penilaian pada SKM ini sesuai dengan Peraturan Menteri Pendayagunaan Aparatur Negara dan Reformasi Birokrasi Nomor 14 Tahun 2017 tentang Pedoman Penyusunan Survei Kepuasan Masyarakat. Unsur-unsur tersebut meliputi:

1. Persyaratan

Persyaratan adalah syarat yang harus dipenuhi dalam pengurusan suatu jenis pelayanan, baik persyaratan teknis maupun administratif.

2. Sistem, Mekanisme, dan Prosedur Prosedur adalah tata cara pelayanan yang dibakukan bagi pemberi dan penerima pelayanan, termasuk pengaduan.

3. Waktu Penyelesaian

Waktu Penyelesaian adalah jangka waktu yang diperlukan untuk menyelesaikan seluruh proses pelayanan dari setiap jenis pelayanan.

4. Biaya/Tarif

Biaya/Tarif adalah ongkos yang dikenakan kepada penerima layanan dalam mengurus dan/atau memperoleh pelayanan dari penyelenggara yang besarnya ditetapkan berdasarkan kesepakatan antara penyelenggara dan masyarakat. 


\author{
NAKHODA: JURNAL ILMU PEMERINTAHAN \\ Edisi Januari - Juni Tahun 2020 Volume: 19 Nomor: 1 \\ ISSN : 1829-5827 | E-ISSN : 2656-5277 \\ DOI : https://doi.org/10.35967/jipn \\ https://nakhoda.ejournal.unri.ac.id/index.php/JIPN
}

5. Produk Spesifikasi Jenis Pelayanan

Produk spesifikasi jenis pelayanan adalah hasil pelayanan yang diberikan dan diterima sesuai dengan ketentuan yang telah ditetapkan. Produk pelayanan ini merupakan hasil dari setiap spesifikasi jenis pelayanan.

6. Kompetensi Pelaksana
Kompetensi
Pelaksana
adalah
kemampuan yang harus dimiliki oleh pelaksana meliputi pengetahuan, keahlian, keterampilan, dan pengalaman.

7. Perilaku Pelaksana

Perilaku Pelaksana adalah sikap petugas dalam memberikan pelayanan.

8. Penanganan Pengaduan, Saran dan Masukan

Penanganan pengaduan, saran dan masukan, adalah tata cara pelaksanaan penanganan pengaduan dan tindak lanjut.

9. Sarana dan prasarana

Sarana adalah segala sesuatu yang dapat dipakai sebagai alat dalam mencapai maksud dan tujuan. Prasarana adalah segala sesuatu yang merupakan penunjang utama terselenggaranya suatu proses (usaha, pembangunan, proyek). Sarana digunakan untuk benda yang bergerak (komputer, mesin) dan prasarana untuk benda yang tidak bergerak (gedung).

\section{KERANGKA TEORI}

\section{Pelayanan Publik}

Salah satu peran Pemerintah dalam kehidupan bernegara adalah memberikan pelayanan yang prima kepada masyarakat sesuai dengan amanat Undang-Undang. Pada pasal 1 Undang-Undang Nomor 25
Tahun 2009 menyebutkan pelayanan publik adalah kegiatan atau rangkaian dalam rangka pemenuhan kebutuhan pelayanan sesuai dengan peraturan perundang-undangan bagi setiap warga negara dan penduduk atas barang, jasa dan/atau pelayanan administratif yang disediakan oleh penyelenggara pelayanan publik. Pengertian ini dapat dipahami bahwa pelayanan publik merupakan kewajiban pemerintah dalam menyelenggarakan pemerintahan, sedangkan dari sisi masyarakat merupakan hak yang harus dipenuhi.

Pelayanan yang baik dan berkualitas seharusnya berdampak kepada kepuasan kepada masyarakat, karena masyarakat secara langsung dapat menilai kinerja pelayanan yang diberikan. Indikator kepuasan masyarakat itulah yang menjadi tolok ukur keberhasilan penyelenggaraan pemerintahan (Hayat dalam Selang \& Jamaluddin, 2019:4). Sebagai penerima pelayanan, masyarakatlah yang paling mengetahui apakah pelayanan yang diberikan sudah baik atau tidak.

\section{Klasifikasi Pelayanan Publik}

Mahmudi (dalam Hardiansyah, 2018:20) mengklasifikasikan pelayanan kebutuhan dasar yang harus diberikan oleh pemerintah dalam 2 kategori, yakni:

a. Pelayanan kebutuhan dasar yang meliputi kesehatan, pendidikan dasar dan bahan kebutuhan pokok masyarakat.

b. Pelayanan Umum yang meliputi pelayanan administratif, pelayanan barang dan pelayanan jasa.

Pada penelitian ini, yang menjadi fokus penelitian adalah berkaitan dengan 


\author{
NAKHODA: JURNAL ILMU PEMERINTAHAN \\ Edisi Januari - Juni Tahun 2020 Volume: 19 Nomor: 1 \\ ISSN : 1829-5827 | E-ISSN : 2656-5277 \\ DOI : https://doi.org/10.35967/jipn \\ https://nakhoda.ejournal.unri.ac.id/index.php/JIPN
}

pelayanan umum, khususnya yang berhubungan dengan pelayanan administrasi karena berkaitan dengan pembayaran pajak.

\section{Asas Pelayanan Publik}

Berdasarkan pasal 4 UndangUndang Nomor 25 Tahun 2009 tentang Pelayanan Publik, asas pelayanan publik terdiri dari:

a. Kepentingan umum;

b. Kepastian hukum;

c. Kesamaan hak;

d. Keseimbangan hak dan kewajiban;

e. Keprofesionalan;

f. Partisipatif;

g. Persamaan perlakuan/tidak diskriminatif;

h. Keterbukaan;

i. Akuntabilitas;

j. Fasilitas dan perlakuan khusus bagi kelompok rentan;

k. ketepatan waktu; dan

1. Kecepatan, kemudahan dan keterjangkauan.

\section{METODE PENELITIAN}

Jenis penelitian yang digunakan pada penelitian ini deskriptif dengan pendekatan kuantitatif. Lokasi penelitian adalah Badan Pendapatan Daerah Kabupaten Bintan yang merupakan unsur pelaksana fungsi penunjang urusan pemerintahan daerah dibidang pengelolaan pajak dan retribusi daerah Kabupaten Bintan.

Populasi adalah wilayah generalisasi yang terdiri atas objek atau subjek yang mempunyai kualitas dan karakteristik tertentu yang ditetapkan oleh peneliti untuk dipelajari dan kemudian ditarik kesimpulannya (Sugiyono,
2012:90). Populasi dalam penelitian ini adalah para penerima pelayanan pada Badan Pendapatan Daerah berkaitan dengan pendapatan daerah (pajak dan retribusi daerah) yakni pajak hotel; pajak restoran; pajak hiburan; pajak reklame; pajak penerangan jalan; pajak mineral bukan logam dan batuan; pajak parkir; pajak air tanah; pajak sarang burung walet; pajak bumi dan bangunan perdesaan dan perkotaan; dan bea perolehan hak atas tanah dan bangunan.

Sampel dalam penelitian ini dipilih secara acak (random sampling) yang ditentukan sesuai dengan cakupan wilayah masing-masing unit layanan. Jumlah sampel dihitung dari jumlah populasi ditambah dengan kemungkinan data eror sebesar 5\%. Penentuan sampel dalam survei ini menggunakan penghitungan berdasarkan tabel penentuan sampel yang dipilih secara acak menurut R. V. Krejcie dan Morgan D.W. (Setiawan, 2007). Total populasi berjumlah 2.459 orang (JanuariOktober 2019) yang mendapatkan pelayanan pada Badan Pendapatan Daerah Kabupaten Bintan . Sedangkan sampel yang diperoleh berdasarkan tabel Krejcie dan Morgan yakni 352 orang.

Selanjutnya metode pengumpulan data dilakukan dengan pengumpulan data sekunder diperoleh dengan menyebarkan kuesioner yang terdiri dari pertanyaan terbuka dan tertutup. Pengisian kuesioner dilakukan dengan cara memberikan kuesioner di masing-masing unit layanan yang berada di Badan Pendapatan Daerah Kabupaten Bintan. Nilai SKM dihitung dengan menggunakan "nilai rata-rata tertimbang" masing-masing unsur pelayanan. Hasil dari SKM unit pelayanan diklasifikasikan ke dalam empat interval 
sebagai berikut:

Tabel 1

Nilai/Skor Persepsi, Interval SKM, Interval Konversi SKM, Mutu Pelayanan dan Kinerja Unit Pelayanan

\begin{tabular}{ccccc}
\hline $\begin{array}{c}\text { Nilai } \\
\text { Persepsi }\end{array}$ & $\begin{array}{c}\text { Nilai/Skor } \\
\text { interval SKM }\end{array}$ & $\begin{array}{c}\text { Nilai Interval } \\
\text { Konversi SKM }\end{array}$ & $\begin{array}{c}\text { Mutu } \\
\text { Pelayanan }\end{array}$ & $\begin{array}{c}\text { Kinerja Unit } \\
\text { Pelayanan }\end{array}$ \\
\hline 1 & $1,00-2.5996$ & $25.00-64.99$ & D & Tidak Baik \\
2 & $2.60-3.064$ & $65.00-76.60$ & C & Kurang Baik \\
3 & $3.0644-3.532$ & $76.61-88.30$ & B & Baik \\
4 & $3,5324-4.00$ & $88.31-100.00$ & A & Sangat Baik \\
\hline
\end{tabular}

Sumber: Peraturan Menteri Pendayagunaan Aparatur Negara dan Reformasi Birokrasi Republik Indonesia Nomor 14 Tahun 2017 Tentang Pedoman Penyusunan Survei Kepuasan Masyarakat Unit Penyelenggara Pelayanan Publik

\section{HASIL DAN PEMBAHASAN}

a. Deskripsi Karakteristik Responden

Penyajian data pada penelitian ini berupa karakteristik responden berdasarkan jenis kelamin, usia, tingkat pendidikan, pekerjaan dan jenis layanan yang diterima. Data yang diperoleh menunjukkan jenis kelamin responden pada penelitian ini hampir berimbang, yakni $49,72 \%$ merupakan responden berjenis kelamin laki-laki dan 50,28\% berjenis kelamin perempuan. Karakteristik responden berdasarkan usia sebagian besar responden berusia 31-40 tahun sebanyak $39,20 \%$ dan paling sedikit berusia 11-20 tahun sebesar $1,14 \%$. Responden dengan rentang usia $21-30$ sebesar $11,08 \%$. Usia 41-50 dengan jumlah responden $28,13 \%$, usia 51-60 dengan jumlah 16,76\% dan usia diatas 61 tahun yang berjumlah $3,69 \%$. Berdasarkan tingkat pendidikan responden terbanyak adalah dengan latar pendidikan SMA 54,26\% dan terendah adalah berpendidikan S2 sebesar $0,28 \%$. Responden berdasarkan pekerjaan didominasi pilihan jawaban lainnya (diluar pilihan jawaban PNS, TNI, POLRI, Swasta dan Wirausaha) yang kebanyakan merupakan Ibu Rumah Tangga sebesar $44,60 \%$ dan jenis pekerjaan terendah responden adalah TNI sebanyak 0,28\%. Karakteristik responden berdasarkan jenis pelayanan didominasi responden yang mendapatakan jenis pelayanan Pajak Bumi dan Bangunan Perdesaan dan Perkotaan (PBBPP) yakni 85,23\% diikuti pajak restoran $13,35 \%$. 


\section{b. Hasil dan Pembahasan}

Tabel 2

Indeks Kepuasaan Masyarakat (IKM)

Badan Pendapatan Daerah Kabupaten Bintan per Unsur Pelayanan

\begin{tabular}{ll} 
No & \multicolumn{1}{c}{ Unsur Pelayanan } \\
U1 & Persyaratan \\
U2 & Sistem, Mekanisme, dan Prosedur \\
U3 & Waktu Penyelesaian \\
U4 & Biaya/Tarif \\
U5 & Produk Spesifikasi Jenis Pelayanan \\
U6 & Kompetensi Pelaksana \\
U7 & Perilaku Pelaksana \\
U8 & Penanganan Pengaduan, Saran dan \\
U9 & Masukan \\
Sarana dan prasarana
\end{tabular}

NILAI IKM BADAN PENDAPATAN DAERAH

Sumber: Olahan Data Primer, 2019

Berdasarkan data tabel di atas dapat dilihat bahwa ada 2 unsur pelayanan yang mendapatkan mutu A yakni unsur keempat berkaitan biaya/tarif dengan nilai indeks sebesar 90,84 dengan skor senilai 3,634 dan unsur kedelepan yaitu unsur Penanganan Pengaduan, Saran dan Masukan dengan nilai indeks sebesar 88,99 dengan skor senilai 3,560. Kedua unsur ini mendapatkan penilaian dengan tingkat kinerja sangat baik.

Sementara, berdasarkan pada tabel di atas tujuh unsur pelayanan yang lain mendapatkan mutu B dengan tingkat kinerja baik dengan urutan tertinggi yakni unsur keenam berkaitan dengan kompetensi pelaksana dengan nilai indeks 85,95 dengan skor nilai 3,438. Diikuti unsur kesembilan berkaitan dengan sarana dan prasarana dengan nilai indeks 84,52 dengan skor nilai 3,381. Unsur pertama

$\begin{array}{cccc}\text { Nilai } & \text { Skor } & \text { Mutu } & \text { Kinerja } \\ \text { IKM } & & \text { B } & \text { BAIK } \\ 84,38 & 3,375 & \text { B } & \text { BAIK } \\ 81,82 & 3,273 & \text { B } & \text { BAIK } \\ 82,67 & 3,307 & \text { B } & \text { SANGAT BAIK } \\ 90,84 & 3,634 & \text { A } & \text { BAIK } \\ 82,24 & 3,290 & \text { B } & \text { BAIK } \\ 85,94 & 3,438 & \text { B } & \text { BAIK } \\ 84,23 & 3,369 & \text { B } & \text { SANGAT BAIK } \\ 88,99 & 3,560 & \text { A } & \text { BAIK } \\ 84,52 & 3,381 & \text { B } & \text { BAIK } \\ \mathbf{8 4 , 2 2} & \mathbf{3 , 3 6 9} & \text { B } & \end{array}$

yakni unsur persyaratan yang mendapatkan nilai indeks sebesar 84,38 dengan skor nilai 3,375. Berikutnya adalah unsur ketujuh yang berkaitan dengan perilaku pelaksana dengan nilai indeks 84,23 dengan skor nilai 3,369. Unsur berikutnya adalah unsur ketiga yaitu waktu penyelesaian dengan nilai indeks 82,67 dengan skor nilai 3,307. Selanjutnya, adalah unsur kelima yakni produk spesifikasi jenis layanan yang mendapatkan nilai indeks sebesar 82,24 dengan skor nilai 3,29. Dan unsur terakhir yang mendapatkan nilai terendah adalah unsur kedua yaitu unsur sistem, mekanisme dan prosedur dengan nilai indeks 81,82 dengan skor nilai 3,273.

Secara keseluruhan nilai Indeks Kepuasan Masyarakat yang terhadap pelayanan yang diberikan oleh Badan Pendapatan Daerah Kabupaten Bintan 


\author{
NAKHODA: JURNAL ILMU PEMERINTAHAN \\ Edisi Januari - Juni Tahun 2020 Volume: 19 Nomor: 1 \\ ISSN : 1829-5827 | E-ISSN : 2656-5277 \\ DOI : https://doi.org/10.35967/jipn \\ https://nakhoda.ejournal.unri.ac.id/index.php/JIPN
}

sebesar 84,22 dengan skor 3,369 dan mendapatkan kinerja baik. Pembahasan setiap unsur pelayanan dapat disajikan sebagai berikut:

\section{Persyaratan}

Untuk menilai persepsi responden mengenai unsur persyaratan tentang pendapat kesesuaian pelayanan dengan jenis pelayanan di Badan Pendapatan Daerah Kabupaten Bintan, maka item persepsinya dibagi menjadi 4 yaitu: tidak sesuai, kurang sesuai, sesuai, dan sangat sesuai. Berdasarkan dari tabel di atas dapat dilihat bahwa persentase tertinggi adalah pada kategori sesuai yaitu 213 atau $61 \%$, kemudian sangat sesuai 136 atau 39\% responden. Terdapat 2 reseponden yang menjawab kurang sesuai dan hanya 1 responden yang merasa bahwa persyaratan yang harus dipenuhi tidak sesuai dengan jenis pelayanan yang diterima. Berdasarkan persepsi tersebut, menunjukkan bahwa persyaratan yang harus dipenuhi oleh masyarakat sudah sesuai dengan 11 jenis pelayanan yang tersedia di Badan Pendapatan Daerah Kabupaten Bintan. Hal ini juga dibuktikan dengan nilai IKM yang didapat.

Persyaratan menjadi salah satu faktor yang mempengaruhi kualitas pelayanan, persyaratan yang diperlukan haruslah diminimalisir dan benar-benar diperlukan hal ini sejalan dengan apa yang dinyatakan Ratminto (Yusriadi, 2018:97)

\section{Sistem, Mekanisme, dan Prosedur}

Dalam memberikan pelayanan kepada masyarakat ada sistem, mekanisme dan standard operasional prosedur (SOP) yang harus dijalankan oleh Badan Pendapatan Daerah Kabupaten Bintan.
Persepsi responden mengenai sistem, mekanisme dan prosedur dibagi menjadi 4 yaitu: tidak mudah, kurang mudah, mudah dan sangat mudah. Berdasarkan hal tersebut maka dari tabel diatas dapat dilihat bahwa sistem, mekanisme dan prosedur pelayanan yang diberikan oleh Badan Pendapatan Daerah Kabupaten Bintan dianggap mudah oleh masyarakat berdasarkan hasil jawaban dari 210 responden atau setara dengan $60 \%$. Beberapa lainnya bahkan menyatakan sangat mudah yaitu 122 atau 35\% responden. Sehingga dapat disimpulkan bahwa prosedur pelayanan mudah dimengerti oleh masyarakat.

Namun ada juga responden yang menjawab sistem, mekanisme dan prosedur yang ada kurang mudah sebanyak 14 atau 4\% responden dan tidak mudah sebanyak 6 responden yang setara dengan 6\%. Hal ini karena ada salah satu jenis pelayanan, yakni Bea Perolehan Hak Atas Tanah dan Bangunan (BPHTB) yang pelayanannya tidak dapat dilakukan di tingkat UPTD (Unit Pelaksana Teknis Daerah) karena nomor billing hanya bisa dikeluarkan oleh Badan Pendapatan Daerah Kabupaten Bintan. Hal inilah yang menyebabkan unsur kedua ini mendapatkan nilai terendah dibandingkan dengan unsur lainnya.

\section{Waktu Penyelesaian}

Waktu adalah hal yang sangat fundamental pada era digital ini dimana kemudahan dan kecepatan juga menjadi salah satu tolak ukur terutama saat memberikan pelayanan kepada masyarakat. Oleh karena itu, waktu penyelesaian menjadi salah satu indikator yang digunakan untuk menilai kepuasan 


\author{
NAKHODA: JURNAL ILMU PEMERINTAHAN \\ Edisi Januari - Juni Tahun 2020 Volume: 19 Nomor: 1 \\ ISSN : 1829-5827 | E-ISSN : 2656-5277 \\ DOI : https://doi.org/10.35967/jipn \\ https://nakhoda.ejournal.unri.ac.id/index.php/JIPN
}

masyarakat dalam mendapatkan pelayanan. Berdasarkan kecepatan waktu pemberian pelayanan dibagi menjadi 4 item yaitu : tidak cepat, kurang cepat, cepat, sangat cepat. Berdasarkan tabel di atas dapat dilihat bahwa sebanyak 200 responden atau setara dengan $57 \%$ menyatakan cepat dan 132 lainnya atau setara dengan 38\% menyatakan sangat cepat. Namun ada 16 orang atau 5\% lainnya yang menyatakan kurang cepat bahkan tidak cepat sebanyak 4 orang atau 1\%. Berdasarkan hasil perhitungan dari jawaban tersebut, waktu yang dibutuhkan dalam penyelesaian sebuah pelayanan relatif cepat. Responden yang menjawab tidak cepat atau kurang cepat berkaitan dengan waktu pelayanan diakibat pelayanan yang diterima pada jasa layanan BPHTB. Keterlambatan dikarenakan nomor billing yang hanya bisa diperoleh melalui Badan Pendapatan Daerah Kabupaten Bintan sehingga memerlukan tambahan waktu dan terkesan tidak cepat atau kurang cepat.

\section{Biaya/Tarif}

Kewajaran tarif dalam pelayanan juga menjadi pertimbangan penting bagi masyarakat. Dalam hal ini biaya atau tarif dalam pelayanan yang diberikan dibagi menjadi 4 item yaitu : sangat mahal, cukup mahal, murah, gratis. Berdasarkan tabel tersebut diatas sebanyak 240 responden atau setara dengan $68 \%$ menyatakan bahwa tarif pelayanan gratis dan beberapa lainnya sebanyak 96 orang atau 27\% menyatakan murah. Dengan angka persentase yang tinggi dapat diketahui bahwa tarif pelayanan yang diberikan kepada masyarakat gratis atau tidak dipungut biaya. Responden yang menjawab adanya biaya pelayanan yang harus dikeluarkan sehingga dipersepsikan mahal dan sangat mahal adalah wajib pajak yang menggunakan jasa pihak ketiga untuk mendapatkan pelayanan.

\section{Produk Spesifikasi Jenis Pelayanan}

Kesesuaian antara produk pelayanan dengan hasil yang diterima oleh masyarakat juga mempunyai nilai tersendiri bagi masyarakat, sehingga apabila tidak sesuai tentunya akan menimbulkan kekecewaan. Hasil pelayanan yang diterima oleh masyarakat pada Badan Pendapatan Daerah Kabupaten Bintan haruslah sesuai dengan aturan, ketentuan dan regulasi yang berlaku. Berdasarkan tabel di atas dapat dilihat bahwa 218 orang responden atau $62 \%$ menyatakan bahwa sesuai antara kesesuaian produk pelayanan yag tercantum dengan hasil yang diterima oleh masyakarat. Bahkan 121 atau 34\% diantaranya menyatakan sangat sesuai. Hal ini menunjukkan bahwa pelayanan yang diberikan oleh Badan Pendapatan Daerah Kabupaten Bintan sesuai dengan ketentuan dan regulasi yang berlaku.

\section{Kompetensi Pelaksana}

Pelaksana haruslah memiliki kompetensi yang meliputi pengetahuan, keahlian, keterampilan dan pengalaman dalam pelayanan (Suharto 2019:112). Kompetensi petugas dalam memberikan pelayanan juga dapat memepengaruhi kualitas pelayanan dan hasil dari pelayanan tersebut kepada masyarakat. Dari tabel di atas dapat dilihat bahwa petugas yang memberikan pelayanan kepada masyarakat Kabupaten Bintan dinilai kompeten oleh 190 orang atau $54 \%$ responden, 158 lainnya atau sebanyak $45 \%$ menyatakan 


\author{
NAKHODA: JURNAL ILMU PEMERINTAHAN \\ Edisi Januari - Juni Tahun 2020 Volume: 19 Nomor: 1 \\ ISSN : 1829-5827 | E-ISSN : 2656-5277 \\ DOI : https://doi.org/10.35967/jipn \\ https://nakhoda.ejournal.unri.ac.id/index.php/JIPN
}

sangat kompeten dan hanya 4 responden atau $1 \%$ yang menyatakan tidak kompeten.

Hal tersebut bermakna bahwa responden menilai pelaksana pelayanan dinilai berkompeten dalam menjalankan proses pelayanan. Sumber daya manusia yang dimiliki oleh Badan Pendapatan Daerah Kabupaten Bintan khusunya dibidang pelayanan sudah sangat baik sehingga mampu memberikan informasi mengenai persyaratan, prosedur, biaya, dan hal-hal lain berkaitan dengan produk pelayanan yang diinginkan masyarakat.

\section{Perilaku Pelaksana}

Keramahan dan kesopanan menjadi nilai penting dalam kehidupan sehari-hari terlebih lagi apabila hal ini menyangkut pelayanan kepada masyarakat karena dengan keramahan dan kesopanan dari para petugas pemberi layanan maka akan terjalin komunikasi yang baik dan juga adanya kenyamanan antara satu dan lainnya. Berdasarkan tabel yang ada diatas dapat dilihat bahwa 201 atau 57\% reponden menyatakan bahwa petugas pemberi layanan bersikap sopan dan ramah bahkan 142 atau 40\% lainnya menyatakan sangat sopan dan ramah. Hal ini sangat baik sekali dan mendapat respon yang positif dari masyarakat. Namun ada juga 6 orang atau $2 \%$ yang menyatakan kurang sopan dan ramah bahkan ada $1 \%$ atau 3 orang menyatakan tidak ramah.

Dari hasil ini dapat disimpulkan bahwa perilaku pelaksana pelayanan pada Badan Pendapatan Daerah Kabupaten Bintan sudah sopan dan ramah, hal ini sejalan dengan hasil persepsi responden pada unsur kompetensi pelaksana.
8. Penanganan Pengaduan, Saran dan Masukan

Dalam pelayanan, pengaduan merupakan hal yang juga sangat dibutuhkan masyarakat apabila terjadi kendala dalam pengurusan atau bahkan untuk mencari infromasi yang diperlukan. Menurut tabel persepsi responden mengenai penanganan pengaduan, saran dan masukan maka dapat dilihat bahwa mayoritas yakni 211 responden atau 60\% repsonden menyatakan dikelola dengan baik. 130 responden atau $37 \%$ menjawab berfungsi kurang maksimal. Berikutnya 8 responden atau $2 \%$ meresponden ada tetapi tidak berfungsi dan hanya 3 responden atau $1 \%$ yang memberikan persepsi tidak ada.

Hal tersebut bermakna bahwa dalam hal penanganan pengaduan, saran dan masukan dinilai dikelola dengan baik. Pengaduan, saran dan masukan dari masyarakat mengenai pelayanan yang diberikan oleh Badan Pendapatan Daerah Kabupaten Bintan diterima dan ditindaklanjuti dengan baik oleh pelaksana.

\section{Sarana dan Prasarana}

Kualitas sarana dan prasarana dalam pelayanan juga menjadi penilaian yang perlu diperhatikan. Berdasarkan tabel sarana dan prasarana dapat dilihat bahwa 192 atau 55\% responden menyatakan bahwa sarana dan prasarana yang dimiliki oleh Badan Pendapatan Daerah Kabupaten Bintan dalam memberikan pelayanan kepada masyarakat dalam kondisi baik. 147 responden atau $42 \%$ menjawab sangat baik, sementara responden yang menjawab cukup hanya 13 orang atau $4 \%$ dan tidak ada responden yang menjawab buruk.

Masyarakat yang memberikan persepsi cukup terhadap sarana dan 


\author{
NAKHODA: JURNAL ILMU PEMERINTAHAN \\ Edisi Januari - Juni Tahun 2020 Volume: 19 Nomor: 1 \\ ISSN : 1829-5827 | E-ISSN : 2656-5277 \\ DOI : https://doi.org/10.35967/jipn \\ https://nakhoda.ejournal.unri.ac.id/index.php/JIPN
}

prasarana yang dimiliki oleh Badan Pendapatan Daerah Kabupaten Bintan merasa perlu adanya pengaturan parkir, mengingat Badan Pendapatan daerah Kabupaten Bintan berada dipinggir jalan umum dan bersebelahan dengan pusat perbelanjaan yang selalu ramai.

\section{KESIMPULAN}

Survei Kepuasan Masyarakat yang dilakukan pada Badan Pendapatan Daerah Kabupaten Bintan menghasilkan kesimpulan sebagai berikut:

1. Nilai Indeks Kepuasan Masyarakat (IKM) Badan Pendapatan Daerah Kabupaten Bintan adalah senilai 84,22 dan skor senilai 3,369. Nilai ini dikategorikan pada Mutu B dengan tingkat kinerja Baik.

2. Ada dua unsur dengan kinerja Sangat Baik dan angka Mutu A yakni unsur biaya/tarif dengan nilai IKM senilai 90,84 dan skor senilai 3,634 dan unsur penanganan pengaduan, saran dan masukan dengan nilai IKM senilai 88,99 dan skor senilai 3,56.

3. Tujuh unsur mendapatkan penilaian kinerja Baik dan angka Mutu B. Unsurunsur tersebut adalah kompetensi pelaksana nilai IKM senilai 85,94 dan skor senilai 3,438; sarana dan prasarana nilai IKM senilai 84,52 dan skor senilai 3,381; persyaratan nilai IKM senilai 84,38 dan skor senilai 3,375; perilaku pelaksana nilai IKM senilai 84,23 dan skor senilai 3,369; waktu penyelesaian nilai IKM senilai 82,67 dan skor senilai 3,307; produk spesifikasi jenis layanan nilai IKM senilai 82,24 dan skor senilai 3,29; serta unsur sistem, mekanisme dan prosedur nilai IKM senilai 81,82 dan skor senilai 3,237.
Survei Kepuasan Masyarakat pada Badan Pendapatan Daerah Kabupaten Bintan menghasilkan rekomendasi kepada Badan Pendapatan Daerah Kabupaten Bintan untuk melaksanakan hal-hal sebagai berikut.

1. Melakukan Pengintegrasian dan Penyederhanaan Prosedur, Persyaratan serta Waktu Pelayanan antara antara UPTD dengan Badan Pendapatan Daerah Kabupaten Bintan.

2. Memberikan kewenangan kepada UPTD agar pengambilan nomor billing dapat dilakukan di UPTD terdekat untuk mempersingkat waktu pelayanan.

3. Sosialisasi mengenai penggunaan manfaat tapping box dan membantu pihak WP (Wajib Pajak) dalam menyiapkan sumber daya dan sarana

\section{DAFTAR PUSTAKA}

Hardiyansyah, H.

Pelayanan Publik: Konsep,

Dimensi, Indikator dan

Implementasinya. Gava Media.

Sellang, K., Sos, S., AP, M., Jamaluddin, D. H., Sos, S., Si, M., ... \& Si, M. (2019). Strategi dalam Peningkatan Kualitas Pelayanan Publik: Dimensi, Konsep, Indikator dan Implementasinya. Penerbit Qiara Media.

Setiawan, N. (2007). Penentuan ukuran sampel memakai rumus slovin dan tabel krejcie-morgan: telaah konsep dan aplikasinya. Universitas Padjadjaran. Bandung. 
NAKHODA: JURNAL ILMU PEMERINTAHAN

Edisi Januari - Juni Tahun 2020 Volume: 19 Nomor: 1

ISSN : 1829-5827 | E-ISSN : 2656-5277

DOI : https://doi.org/10.35967/jipn

https://nakhoda.ejournal.unri.ac.id/index.php/JIPN

Sugiyono. (2012).Metode Penelitian Kuantitatif, Kualitatif dan $R \& D$. Bandung: Alfabeta.

Suharto, Sugeng. (2019). Kajian Survey Layanan Publik dan Kebijakan Pemerintah daerah Propinsi Bengkulu dalam Bidang Kesehatan (2018) (Studi Kualitas Layanan pada Rumah Sakit Umum Daerah di Wilayah Bengkulu). Ponorogo: Uwais Inspirasi Indonesia.
Yusriadi. (2018).Reformasi Birokrasi dalam Pelayanan Publik. Yogyakarta: Deepublish.

Undang-Undang Nomor 25 Tahun 2009 tentang Pelayanan Publik.

Peraturan Menteri Pendayagunaan Aparatur Negara dan Reformasi Birokrasi Nomor 14 Tahun 2017 tentang Pedoman Penyusunan Survei Kepuasan Masyarakat. 